$\begin{array}{r}\text { Volume and Issues Obtainable at Center for Sustainability Research and Consultancy } \\ \text { Journal of Business and Social Review in Emerging Economies } \\ \text { ISSN: 2708-2172 \& (E): 2708-2504 } \\ \text { Volume 7: Issue 3 September 2021 } \\ \text { ᄃSRᄃ } \\ \text { Journal homepage: www.publishing.globalcsrc.org/jbsee } \\ \hline\end{array}$

\title{
Impact of Private TV Channels and its Commodification of Religious Programs
}

Faisal Jahan, Islamia University Bahawalpur, Bahawalpur, Pakistan

*Ghulam Shabir, University of Central Punjab, Lahore, Pakistan

*Corresponding author's email address: drshabair@yahoo.com

\begin{tabular}{l}
\hline ARTICLE DETAILS \\
\hline History \\
Revised format: Aug 2021 \\
Available Online: Sep 2021 \\
\hline Keywords: \\
Commodification, Religious \\
Programs, TV Channels, \\
Moxed method, Survey, \\
Content Analysis.
\end{tabular}

JEL Classification

L80, L82

\section{open $\partial$ access}

\section{ABSTRACT}

Purpose: This paper examined some societies; religion itself is a complex subject, and then creating its content in the media is no less of a challenge. Especially in a society like Pakistan, where people are more sensitive in the name of religion and what is being said on TV soon spreads like wildfire on social media. The study looked at the extent to which Pakistani TV channels believe in commercialism and how far they can go for this purpose. To what extent has the aspect of commodification been embedded in Pakistani TV channels? One of the purposes of this research is to obtain and rate advertisements for the content produced and presented for TV. The questions are severe, and two different approaches have been adopted in the research method to find the answers.

Design/Methodology/Approach: This study deals with the religious media contents and its public. This method is most commonly used in clinical research, schools, social organizations, or the research in which the domain is fixed. The systematic random sampling technique is applied in the selection of contents. This study reveals the religious commercialization and commodification done by Pakistani television channels. Due to the specification of the nature of TV contents, relevance is the most obvious factor.

Findings: The finding shows that the majority opinion, the religious qualifications of the anchors of religious programs or their grasp on religious subjects are not much appreciated? In addition, the analysis of the material revealed that commercial advertisements run during religious shows on Pakistani TV channels. Still, at the same time, segments are also produced on a commercial basis..

Implications/Originality/Value: Religious content can be studied from further angles with regard to innovation and change for commercial purposes. These include the use of music, the movements of anchors in religious shows, the dissent of religious scholars, the use of glamor in religious programs, and the sale of life in the name of religion.

(C) 2021 The authors, under a Creative Commons AttributionNonCommercial- 4.0 
Recommended citation: Jahan, F. and Shabir, G. (2021). Impact of Private TV Channels and its Commodification of Religious Programs. Journal of Business and Social Review in Emerging Economies, 7 (3), 725-736.

\section{Introduction}

First of all, the term "Commodification" is necessary to define before assessing the other elements of this study. Karl Marx (1967) defined it as "the transformation of goods and services, as well as ideas or other entities that normally may not be considered good, into a commodity." The Marxist approach regarding commodity is changed from the terminology used in economics. Under the economics orders, the business dictionary defined Commodity as "A Reasonably interchangeable good or material, bought and sold freely as an article of commerce. Commodities include agricultural products, fuels and metals and are traded in bulk on a commodity exchange or spot market". But the Marxist approach deals with a different idea. In other words, commoditization is about proprietary things becoming generic, whereas commodification is about un-salable things becoming salable.

The social values replace each other with time according to trends and practices of the society in different sections. It also depends on different factors as Rushkoff (2005) explained the process according to the Marxist political approach and argued that commodification is the process in which the things that do not have value attain the value. It also deals with the values replacement in society. He explained that commerce was not interested in the relations of people in the past, but nowadays, the relationships in routine life are most important for commerce.

In the modern era, commodities are heavily influenced by values. The media plays a vital role in making up the public's minds as Mosco (1996) argued that political economy is the primary reason for commodifying media content. Commodification is the transformation of values and norms according to commodities and their value. In the shape of commodification, the persons and societies search for their values in products. There is a system of economics in which people purchase the products according to their needs, but commodification changes the values. After its implication of commodification, people purchase the things even they need or not. Same on this pattern, mass media plays with the ideology and thoughts of users, and even there is an excellent depiction of the commodification of audience and electronic info regarding use practices. Religions are very well aware of the importance of mass media and its use to promote their ideologies and spirituality. The mass media is involved in the commodification process using religion and spirituality following economic aims.

\section{Religious Commodification}

Religion is a passionate and warm topic of the world, and there is an excellent tens hype continued at the international level due to religious issues. Religion is more influential in the conversion of social values all over the world. The people mostly follow the religion and can easily divert themselves under the religious values. That is why religious commodification is a top level highly rising issue globally. Davie (2007) concluded that there are some worldwide facts and ground realities in religion. Still, these global phenomena are also facing the challenge of societies' perceptions under their norms and cultures. The economy of the international market is growing and has been developed at a higher level. Some factors are significant in the convergence of people on religious points. The work process and practices of the market, the use of advanced and modern technology, and the movement of citizens from one region to another of the world are the key factors in this process. Another most important and helpful factor is the use of capital and information by religious institutions. In the modern era, the different prominent religions are competing with each other and very much interested in research and reinvention to attract the consumers of the religious market.

No need to visit so far places, every religious and sacred commodity is available online now. You can do a query and then order online. You will get everything at your doorstep. If you are a Christian, you have to visit holyart.com; now, you can purchase not only the cross, books, medals, lockets, altar bells, 
incense charcoals, holy statues, frames, and logos, etc. If you are a Pakistani Muslim, you must visit daraz.com and order sacred lockets, counters, the cap for pray, tasbih, Ehrams, and Islamic books. If you are a Hindu and belong to India, then amazon. It is the best option for you to purchase sacred items online. There is Om, Shiva linga, bindi, and tilak and everything related to your religion is available. In short, there is no need to travel anywhere to purchase the pious articles now. It is online commercialization and continues in every religion and region.

\section{Division of Population According to Religion}

Hackett \& McClendon (2017) found that the Christianity is the largest religion of the world as per population. The 31.2 percent world's population is consisted of Christians. Second largest religion of the world is Islam those are 24.1 percent of the total population of world. Hindus are on third place with $15.1 \%$ and Buddhists are forth larger religious strength of world with $6.9 \%$. There is also a huge population of folk religions those are $5.7 \%$ of total of world. There is also a huge amount of nonbelievers in the world and these unaffiliated people are the $16 \%$ of the world's total population.

The religious people are mostly, more social or prosocial rather than irreligious citizen. But both variables are not necessary or conditioned for each other. Saroglou (2012) conducted a study to found that relation between religiosity and sociality and concluded that the religious people consider the deep relation between religion and sociality and even they perceive the pro-sociality as the reason of religion. He found that the religious individuals are more prosocial than the less or non-religious people. But the pro-sociality cannot be link with religion. It is absolutely a different and separate case. He stated the link of both as fallacy.

Religion is very much important part of a common man. It is also a sensitive topic and sometime it can be cause of a great conflict in society. As Salawu (2010) found that Nigeria is a country where the people are divided in more than 400 ethno-religious groups. This conflict is basically between Christians and Muslims. He concluded that there are different angles and reasons of these conflicts. Ethno-religious and political leaders are the major cause of these conflicts. The society is consisted on followers of these leaders. These conflicts had been led to severe crises in whole country. Juergensmeyer (2006) argued that religion is always Anti-America, Anti-modernism and Anti-globalization. Religion causes for such type of conflicts in world and also in specific societies. Religion creates an image of cosmic war in its followers that can be cause to formulate the religious militant groups and forces.

\section{Statement of Problem}

Hassan (2014) highlighted that the media trends and religious presentations were affected and changed after the 9/11 incident. Western media highly exposed Islam and Muslims as terrorists. On another side, the Muslim media also presented the West or USA as the enemy of Muslims. Eastern media was accusing the United States of a significant cause of destroying the world's peace for its dominance all over the earth. A media revolution happened in Pakistan in 2002 when Chief Martial law administrator and President of Pakistan General Pervez Musharraf introduced the private media channels in Pakistan. That was the peak time of conflict between the Western world and Muslim nations. There was a great responsibility on the shoulder of newly introduced TV news media in Pakistan. But the results were diverse as compared to the expectations of General Pervez Musharraf. Electronic news media of Pakistan promoted and encouraged the different causes of terrorists. They also introduced and developed the Anti-America and Anti-West narratives. Private news TV channels depicted the contents with a radical approach. On other angles, the moderate school of thought was not highlighted by this media.

\section{Objectives of Study}

1. To explore the use of dramatization and over-emotionalism in religious television programs to throw emotional appeal to viewers in Pakistan.

2. To assess the agenda of Pakistani TV channels when they design and produce religious content. 
3. To assess the commercialization factor in Pakistani religious TV programs.

4. To explore the role of mainstream TV channels when they offer precious gifts and prizes to viewers in religious TV programs to increase the audience.

\section{Literature Review}

The Indonesian media industry is one of the best industries in the Muslim world. They follow the Islamic culture and teachings in their media contents but are also aware of the market demand. Muzakki (2010) found that Indonesian media is mainly concentrated and focused on teenagers regarding religious content. Their spiritual contents, including historical presentations, are mainly produced for the young generation. Christophorou \& Spyridou (2017) exposed that two religions are racing against each other in Cyprus. Greek Junta and Latin are introduced as a religious group or called a Greek community. Turkish Cypriots are Muslims and are recognized as a separate religious and ethnic group within the country. The nation is also strongly divided in left and right cleavage. In this extraordinarily polarized nation, the people are divided politically and religiously, and media debates on political issues are also full of biases. Kiriya (2011) holds his research to analyze the agenda-setting and programing of State TV of Russia and the public sector's pure commercial television channels. The private and commercial media, with their editorial policy, is also working in the state. State use two different processes to produce media content for their channels. State invests in production directly, or they invite the advertisers to finance the content. In both conditions, commodification is found as per market demand in their media contents.

Sudcharoen (2013) exposed that issue of abortion is a confusing and contradictory topic in Thai society. As per the teachings of Buddhism, abortion is a terrible act and can be the reason to destroy the fate of the doer. The 1980s was the period when social activists raised their voices to legalize it. However, their demand was not accepted by the government. This is a warm topic and commodified at many platforms in the next decade, including mass media. This was introduced in Thailand as "Kaekam." While the dominant discourse has long depicted abortion as a life-destroying act from a Buddhist perspective, the emphasis on embodied karma in the form of vengeful child ghosts, the ability to change one's karma through certain rituals and confessions by those involved in abortions is all recent. This narrative was popular and discussed on a larger scale for a long time. Some groups were allowed to earn money by curing the affected people via the commercialization of karma.

Moberg \& Granholm (2017) concluded that in the post-secular era, the practices are different in different societies. Society is heavily influenced by religiosity will deal in brutal manners with the minorities and secular minds. But a multicultural society can be calm and soft in religious manners. Maybe their media contents are also influenced by the secular approach. The media's approach in such regions may be antireligiosity and religious forces can be depicted negatively as Lovheim (2013) explored the relationship between religion, media, and culture. She put the example of Middle East conflicts and highlighted that gender is discriminatory even in social media. New media played a vital role during the revolutions in the 21 st century when people used it at a larger scale to collect the gathering and make the campaigns successful. But at the same time, this media played a discriminated role in the projection of females. Casey (2006) concluded that the majority of American internet users use it for religious purposes. But it is not a matter of America only, but people of every part of the world take an interest in their religion profound. Sometimes religion is not easy to adapt for a general person. There are varied norms and values in different societies. These differences can create a hurdle for its follower to adapt and fulfill all teachings of religion. Sometimes a tiny society carries with more than one culture. Richerson and Newson (2008), in their study "Is religion adaptive? Yes, no, neutral, but mostly we don't know," found that religions are diverse.

Television is a powerful tool of religion for promotion and spreading the messages. Religious depiction and characters are needed in a script to make a TV drama successful. The drama designers include the spiritual characters and sacred places to touch the feelings of religious people. Bicer (2013) holds a 
study in Turkey to examine the religious impact of television soap operas having a spiritual script. Findings of the research, the majority of soap operas users, re-shaped the values and spiritual ideologies. On another side, the religious touch was also a significant reason to make these dramas as successful and super hit in the marketplace. Rakhmani (2014), in her another article titled "Mainstream Islam: Television industry practice and trends in Indonesian sensation," concluded that Soap operas (Sinetron) are popular in the middle-class youth of Indonesia. There is a scroll thread between Islamic ideology and secularism. The new investors also found Islamic values as most fruitful and profitable in the Indonesian marketplace, and they followed them for economic purposes. The drama industry of Indonesia is highly profitable because of following the public demand.

KARLIDAĞ \& Bulut (2014) found that the market of Turkish soap operas is spreading toward Middle Eastern states and many other countries. These are enjoying popularity in central and South Asian regions. The modern depiction in Turkish dramas was closer and acceptable for Japan, the Middle East, and some other regions; that is why Turkish soap operas replaced the USA in the Middle East. AbuLughod (2006) concluded that TV was working under the government since in starting days in Egypt. Recently, it has been got freedom from the state and started working for culture and ideological independence. There is a widespread debate about how the private media will handle religious terrorism and its factors with their independent policy. The researcher found that the television contents are forming as per religious and ideological culture.

Rakhmani (2014) found a deep relation between Islam's economy and mass media in the era when the thoughts were in the reshaping process. Religions, norms, systems, and ideologies are re-designing themselves as per the requirements of the market. It is all about the commercialization of religious preach through TV drama productions. That is why Indonesian TV has been introduced as a preaching tool in the country. As a result, traditional, liberal, and conservative Muslims enjoy the same media content designed by a specific mindset.

Hendriyani et al. (2016) hold the quantitative analysis of children's television programs of Indonesian television. The analyses were done between the programs of the 1980s and 2000s. These age groups were found as a misfit for the adult characters as love stories and mismatch with child roles. Spiritual and sometimes magical touch is a helpful factor to hit a film on the box office. Some Film producers very much rely on spiritual scenes in their commercial films. Emest (2017) holds a study to assess the role of African magical television channels in the formulation and promotion of the Nigerian film industry. He found that Nollywood producers attained motivation from the producers of magical television programs that helped them come out from pressure and tension. Production values and practices are changed as the movement of earning money in the mass media industry. But the designing of media content is not an easy job for producers of Nollywood due to the multi-choice society. They are facing complexity and conflicts due to ambiguity in contents.

\section{Hypotheses}

H1. Media is an industry aimed at making money. The majority of people surveyed would convinced that the TV media distorts religious material for commercial purposes and depicts the commodified religious contents at a larger scale.

H2. Pakistan is a society where most men are out of the house for work all day while most women are at home. A closer look at society can make men more critical. Therefore, there is a strong possibility that women viewers would be more gratified than men with religious content or programs on TV.

\section{Theoretical Framework}

This study covers different aspects and angles of commodification, commercial roles of media in the religious sector and economy. That is why the study is related to different theories of media, economics, and social studies. Below, given different theories are interrelated with this study and set the theoretical 
framework.

Media is an excellent industry of the world, and it is expanded due to the concept of globalization. Small media organizations are willing to expand their market more extensively, and large organizations are looking to be conglomerates. As Alexander, Owers, Carveth, Hollifield \& Greco (2003) argued, media economics is more critical in the current age than in any past period. Media and economic are both supporting factors for each other. Media economics has been a separate field of study for the last three decades. This domain deals with the production of communication content and economic principles for the media industry. In addition, this domain of study deals with the social influences of media contents and usage and effects of new media technologies. Researchers introduced a formula of what produced, how produced for whom. Media economics is related to how content is produced for which audience. A target buying market is mainly concentrated by the content producer when it is designed. A media firm designs and produces content according to its target users and uses suitable technology to produce the content.

In short, the media economy is consisted of the production for the marketplace with the aim of maximum earning. Mass media organizations are involved in producing the contents as per public demand. Still, their aim is not to gratify them, but they are just looking to expand their marketplace and business. Com-Revere \& carveth (2003) concluded that public interest is a secondary element for the media firms. They are doing just business, and if they are earning good profit, then they serve in positive manners. Rapidly changed and over-dependency on technology is also a matter of a media investor. To compete and survive in a market, the media firms are bound to carry advanced and modern technology. Handling the marketplace and audience is as essential as carrying the cable operators with a media organization.

\section{Methodology}

This research study explores the role of Pakistani mainstream television channels in the domain of religion and its public perception. Religion is a sensitive topic in all regions of the world, but Pakistan is a more complex society in this perspective. Haneef et al. (2005) found higher intrinsic religious motivation than extrinsic aptitude among university students of Pakistan. The researcher used a mixedmethod approach including content analyses and survey method as research design to collect and analyze the data as Morgan (2007) defined mixed method approach as it has broad interpretations and allows to include different topics and data collection plans including surveys, observations, experiments or ethnographies. It also can relate the assumed data, traits, and values as the type of research method. Johnson, Onwueqbuzie \& Turner (2007) explained that the mixed method could use in both qualitative and quantitative researches. They divided the mixed method into three categories: qualitative dominant, Quantitative dominant, and equal status mixed method.

This study deals with the religious media contents and its public. This method is most commonly used in clinical research, schools, social organizations, or the research in which the domain is fixed. Minimum consumption of money and fewer efforts to work on the population elements are the significant characteristics of this sampling technique. The systematic random sampling technique is applied in the selection of contents. This study reveals the religious commercialization and commodification done by Pakistani television channels. Due to the specification of the nature of TV contents, relevance is the most obvious factor. Therefore, religious television programs and shows are required to examine the media depictions. The researcher chose the Ramazan transmissions of ARY Digital and Geo TV, both the sehri and iftar transmissions.

\section{Findings}

Two different methods are adapted to collect the data in this study as survey method and contents analysis method. In the first session of this chapter, the analyses of Sehri and Iftar transmission of ARY Digital and Geo TV are presented. Geo TV presented its Ramzan transmission entitled "Ehsaas Ramzan." it was telecasted during the holy month of 2019 in Sehri and Iftar timings. Those programs are 
presented on Geo TV network's channel "Geo Entertainment" (Har Pal Geo) and Geo News. Ramzan transmission of Geo TV network was hosted by Rabia Anam, the newscaster of Geo News. On another side, ARY digital telecasted the particular Ramzan transmission entitled "Shan e Ramzan" on ARY Digital and ARY News. Wasim Badami hosted Ramzan transmission of ARY digital, a famous political talk show on ARY News, and co-hosted by "Iqrar ul Hasan," the most popular host of crime story's program "Sar e Aam" on ARY News. The date wise findings of these programs are as under;

6.2.3. Do the Religious TV contents influence the culture and values of society

\begin{tabular}{|c|c|c|c|c|c|}
\hline & & Frequency & Percent & Valid Percent & $\begin{array}{l}\text { Cumulative } \\
\text { Percent }\end{array}$ \\
\hline \multirow[t]{4}{*}{ Valid } & At large Scale & 111 & 22.2 & 22.2 & 22.2 \\
\hline & Yes, but limited & 353 & 70.6 & 70.6 & 92.8 \\
\hline & No & 36 & 7.2 & 7.2 & 100.0 \\
\hline & Total & 500 & 100.0 & 100.0 & \\
\hline
\end{tabular}

Source: Commodification of Religious programs in Pakistani mainstream TV channels: Exploring perception of Pakistani Viewers

\section{Summary}

Chart No. 6.2.3 exposes the public response on influence of religious TV programs on culture and values. Results show that 36(7.2\%) respondents do not feel or accept any influence of religious TV contents on culture and social values. On other side, 111(22.2\%) respondents accepted this influence heavier and at larger scale. Majority of respondents $353(70.6 \%)$ accepted the influence of this factor but at limited scale but not too much.

So, majority of respondents accepted the influence of religious television programs on culture and its values but at limited scale.

6.2.3.1 Education* Do the Religious TV contents influence the culture and values of society Cross-tabulation

\begin{tabular}{|c|c|c|c|c|c|c|}
\hline & & & \multicolumn{3}{|c|}{$\begin{array}{l}\text { Do the Religious TV contents influence the } \\
\text { culture and values of society }\end{array}$} & \multirow[b]{2}{*}{ Total } \\
\hline & & & $\begin{array}{l}\text { At large } \\
\text { Scale }\end{array}$ & $\begin{array}{l}\text { Yes, but } \\
\text { limited }\end{array}$ & No & \\
\hline \multirow[t]{4}{*}{ Education } & Undergraduates & Count & 44 & 190 & 16 & 250 \\
\hline & & $\%$ within Education & $17.6 \%$ & $76.0 \%$ & $6.4 \%$ & $100.0 \%$ \\
\hline & Graduates & Count & 67 & 163 & 20 & 250 \\
\hline & & $\%$ within Education & $26.8 \%$ & $65.2 \%$ & $8.0 \%$ & $100.0 \%$ \\
\hline \multirow[t]{2}{*}{ Total } & & Count & 111 & 353 & 36 & 500 \\
\hline & & $\%$ within Education & $22.2 \%$ & $70.6 \%$ & $7.2 \%$ & $100.0 \%$ \\
\hline
\end{tabular}

Source: Commodification of Religious programs in Pakistani mainstream TV channels: Exploring perception of Pakistani Viewers

\section{Summary}

Chart no. 6.2.3.1 exposes the cross-tabulation of graduate and undergraduate student on the influential factor of religion on culture and values. As per findings of survey, 44 (17.6\%) undergraduate students found as strongly agreed on the influence of religious TV programs on socio-cultural values at larger scale but the majority $190(76 \%)$ respondents accepted this influence at limited level and scale. At same time, $16(6.4 \%)$ respondents absolutely refused to accept the any influence of these programs on society. On other side, 67 (26.8\%) graduate students were considering the religious TV programs as powerfully influential factor for society and culture but 163 (65.2\%) graduate respondents accepted this influence at minimal scale. In this situation, $36(7.2 \%)$ survey respondents refused to accept the any influence of this factor on society or culture.

So, no major difference is found in the opinion of graduate and undergraduate students.

6.2.3.2 Gender * Do the Religious TV contents influence the culture and values of society Cross-tabulation Do the Religious TV contents influence the culture and values of society

\begin{tabular}{llll}
\hline At large Scale & Yes, but limited No & Total
\end{tabular}




\begin{tabular}{|c|c|c|c|c|c|c|}
\hline Gender & Female & $\begin{array}{l}\text { Count } \\
\% \text { within Gender }\end{array}$ & $\begin{array}{l}56 \\
22.4 \%\end{array}$ & $\begin{array}{l}184 \\
73.6 \%\end{array}$ & $\begin{array}{l}10 \\
4.0 \%\end{array}$ & $\begin{array}{l}250 \\
100.0 \%\end{array}$ \\
\hline & Male & $\begin{array}{l}\text { Count } \\
\% \text { within Gender }\end{array}$ & $\begin{array}{l}55 \\
22.0 \%\end{array}$ & $\begin{array}{l}169 \\
67.6 \%\end{array}$ & $\begin{array}{l}26 \\
10.4 \%\end{array}$ & $\begin{array}{l}250 \\
100.0 \%\end{array}$ \\
\hline Total & & $\begin{array}{l}\text { Count } \\
\% \text { within Gender }\end{array}$ & $\begin{array}{l}111 \\
22.2 \%\end{array}$ & $\begin{array}{l}353 \\
70.6 \%\end{array}$ & $\begin{array}{l}36 \\
7.2 \%\end{array}$ & $\begin{array}{l}500 \\
100.0 \%\end{array}$ \\
\hline
\end{tabular}

Source: Commodification of Religious programs in Pakistani mainstream TV channels: Exploring perception of Pakistani Viewers

\section{Summary}

Chart no. 6.2.3.2 highlights the difference of opinion of male and female respondents on influential level of religious TV programs on socio-culture and values. As per results of survey, $56(22.4 \%)$ female respondents accepted the influence at larger scale but $184(73.6 \%)$ respondents accepted this influence at limited scale. At same time, $10(4 \%)$ females absolutely refused to accept the any influence of this factor on society. On male side, $55(22 \%)$ respondents accepted the religious TV programs as heavily influential factor on social values and culture but 169 (67.6\%) respondents accepted it at smaller level. Number of refusers was $26(10.4 \%)$.

So, there is no major difference found in the opinion of male and female respondents on the influential level of religious TV programs on culture and values.

6.2.4. Are Pakistani TV Religious programs helpful to provide religious education to Youth and children?

\begin{tabular}{llllll}
\hline & & Fercent & Valid Percent & $\begin{array}{l}\text { Cumulative } \\
\text { Percent }\end{array}$ \\
\hline Valid & At large Scale & 157 & 31.4 & 31.4 & 31.4 \\
& Yes, but limited & 296 & 59.2 & 59.2 & 90.6 \\
& No & 47 & 9.4 & 9.4 & 100.0 \\
& Total & 500 & 100.0 & 100.0 & \\
\hline
\end{tabular}

Source: Commodification of Religious programs in Pakistani mainstream TV channels: Exploring perception of Pakistani

\section{Summary} Viewers

Graph No. 6.2.4 deals with the role of Pakistani TV religious programs in provision of religious education to the youth. As 157 (31.4\%) respondents of survey religious TV programs are playing vital and good role to promote religious education at large scale. Majority 296 (59.25) respondents stated this role of Pakistani TV at limited scale. There 47 (9.4\%) respondents neglected the educational and teaching role of Pakistani religious TV programs.

So, majority of respondents accepted the role of Pakistani religious TV programs in promotion of religious education but at limited scale.

6.2.4.1 Education * Are Pakistani TV Religious programs helpful to provide religious education to Youth and children? Cross-tabulation

\begin{tabular}{|c|c|c|c|c|c|c|}
\hline & & & \multicolumn{3}{|c|}{$\begin{array}{l}\text { Are Pakistani TV Religious programs } \\
\text { helpful to provide religious education to } \\
\text { Youth and children? }\end{array}$} & \multirow[b]{2}{*}{ Total } \\
\hline & & & $\begin{array}{l}\text { At large } \\
\text { Scale }\end{array}$ & $\begin{array}{l}\text { Yes, but } \\
\text { limited }\end{array}$ & No & \\
\hline \multirow[t]{4}{*}{ Education } & Undergraduates & Count & 89 & 144 & 17 & 250 \\
\hline & & $\%$ within Education & $35.6 \%$ & $57.6 \%$ & $6.8 \%$ & $100.0 \%$ \\
\hline & Graduates & Count & 68 & 152 & 30 & 250 \\
\hline & & $\%$ within Education & $27.2 \%$ & $60.8 \%$ & $12.0 \%$ & $100.0 \%$ \\
\hline \multirow[t]{2}{*}{ Total } & & Count & 157 & 296 & 47 & 500 \\
\hline & & $\%$ within Education & $31.4 \%$ & $59.2 \%$ & $9.4 \%$ & $100.0 \%$ \\
\hline
\end{tabular}

Source: Commodification of Religious programs in Pakistani mainstream TV channels: Exploring perception of Pakistani Viewers 


\section{Summary}

Chart no. 6.2.4.1 explores the variation of opinion between graduate and undergraduate students on role of TV media in provision of religious education to the youth and next generation. As per findings, 89 (35.6\%) undergraduate respondents found agreed on the larger scaled role of TV media in Pakistan in provision of religious education but $144(57.6 \%)$ respondents took a stand on limited role of TV media in this regard. In same category, 17 (6.8\%) respondents refused to accept the any role of Pakistani TV media in this regard. On other side, $68(27.2 \%)$ graduate respondents found inspired of TV media in Pakistan in promotion of religious education in youth and children but $152(60.8 \%)$ graduates were not found as very much inspired but they accepted the performance at smaller scale. Whereas, $30(12 \%)$ respondents absolutely rejected and neglected the role of Paki TV media in this regard. So, there is no major difference found in the opinion of graduate and undergraduate students on the role of TV media in promotion of religious education among youth and children.

6.2.4.2 Gender * Are Pakistani TV Religious programs helpful to provide religious education to Youth and children? Cross-tabulation

\begin{tabular}{|c|c|c|c|c|c|c|}
\hline & & & \multicolumn{3}{|c|}{$\begin{array}{l}\text { Are Pakistani TV Religious programs helpful to } \\
\text { provide religious education to Youth and children? }\end{array}$} & \multirow[b]{2}{*}{ Total } \\
\hline & & & At large Scale & Yes, but limited & No & \\
\hline \multirow[t]{4}{*}{ Gender } & Female & Count & 79 & 154 & 17 & 250 \\
\hline & & $\%$ within Gender & $31.6 \%$ & $61.6 \%$ & $6.8 \%$ & $100.0 \%$ \\
\hline & Male & Count & 78 & 142 & 30 & 250 \\
\hline & & $\%$ within Gender & $31.2 \%$ & $56.8 \%$ & $12.0 \%$ & $100.0 \%$ \\
\hline \multirow[t]{2}{*}{ Total } & & Count & 157 & 296 & 47 & 500 \\
\hline & & $\%$ within Gender & $31.4 \%$ & $59.2 \%$ & $9.4 \%$ & $100.0 \%$ \\
\hline
\end{tabular}

Source: Commodification of Religious programs in Pakistani mainstream TV channels: Exploring perception of Pakistani Viewers

\section{Summary}

Chart no. 6.2.4.2 describes the difference of opinion among male and female respondents of study regarding the role of Pakistani TV media in provision of religious education to youth and children viewers. In this regard, 79 (31.6\%) female respondents were found as strongly agreed for the larger level of role of TV media in this regard but $154(61.6 \%)$ females accepted this role of media at minimal level or limited scale. Whereas, $17(6.8 \%)$ females were found as absolutely not agreed of role of Pakistani TV media in this regard. On other end, 78 (31.2\%) male respondents accepted the solid and strong role of Pakistani TV media in promotion of religious education even, 142 (56.8\%) males accepted this role of media at minimal level in Pakistan but 30 (12\%) respondents absolutely refused to accept the role of Pakistani television channels in this regards. So, no major difference was found in the opinion of male and female respondents regarding the role of Pakistani TV channels in the promotion of religious education.

\section{Discussion}

Religion is a sensitive topic that requires a lot of consideration to discuss. Even societies that call themselves secular seem to be embroiled in the sensitivities and debates of religions. Opinions and debates about religion in the world took a new turn, especially after 9/11. Abbas (2004) argued that if a person is identified with religion, it becomes difficult to live in a society where another culture or religion rules. Especially after 9/11, racism has affected different parts of the world, and the typical person's life has become a dilemma in some societies just because he belongs to another religion.

In the early 21 st century, Islam was the most debated religion during and after the war on terror and the tug-of-war. Mandaville (2009) highlighted that the transnational identity of Muslims across the UK and Europe discussed at length. In the UK, Muslim youth were viewed and discussed in a specific way, especially in the context of security. The religious values, political and social ideologies, and teachings of the Muslims were viewed from a particular point of view and well discussed. Vaparys \& Torrekens 
(2013) researched various dramatic events that took place in the world in the aftermath of the terrorist attacks and examined the changes in the perception of Islam as a result. He noted in his study that the editorial policy of the British Press had seen a marked increase in the debate over Islam and the Muslim community. In the wake of major terrorist attacks by Islamist extremist groups, the British media has raised questions about Muslims' identities and the rights of those living in the UK and Europe.

In Pakistan, entertainment and mainstream TV channels are also at the forefront of showing religion. Only by adding the element of religion in the programs; the sentiments of people are aroused. Continuing the same line, if we talk about the combination of Pakistani media and religion, the contents of news and entertainment channels are equally religious as religious TV channels are. After researching Pakistani TV dramas, Montpellier (2019) concluded that these contents play a vital role in spreading the religion and promoting its values. Similarly, Pakistani dramas not only publicize Islamic traditions and values but also play a vital role in their promotion. However, there are also some opinions against, which are radically different regarding the role of Pakistani media in religious depiction. (Malik \& Lalani (2012) clarified that the flow of information is from west to east and the secular system imposed and promoted by the western media. The media of the Islamic country of Pakistan is also under pressure to adopt a secular approach. As a result, there are outrageous programs in the Pakistani media in the name of fashion that appear to violate Islamic teachings. Safdar, Shabir \& Khan (2018) indicated the editorial policy of Pakistani media in this regard. They described the role of Pakistani media in raising political awareness and promoting education as a good and encouraging step towards nation-building. At the same time, The role of the media in Pakistan in promoting religious values and social welfare has been disappointing.

Along with religion, the media has also been careless in exposing its own culture and playing its role in its development, while highlighting and promoting culture is one of the primary duties of the media. This study covers the role of Pakistani media in religion. While reviewing the editorial policy on the religion of Pakistani TV channels, the researcher also exposed the modifications in religious contents following the impact of their editorial policy on commercialism. To uncover such facts where the analysis of the TV contents for a public survey also made a part of this research. Let's take a step-by-step look at what the study's hypotheses were and what the results are.

\section{Conclusion}

The results of this study also revealed that Pakistani viewers believe that the younger generation is attracted to religion and participates in religious TV programs. Sigalow, Shain \& Bergey (2012) revealed that for the younger generation, religion not only provides guidance at every step of life but also strengthens their decision-making power. The younger generation seeks guidance from religion for important decisions. Young people who are guided by religion. They make decisions quickly in the light of religious guidelines, such as marriage matters, how many children they should have, employment choices and business matters, where to stay and how to live, etc. Diez, Mico \& Sabate (2017) confirmed that the younger generation is more passionate about religion and religious observances. But at the same time, they exposed some of the elements behind it. According to the results of their extensive survey, the environment and background accelerate religious practices. Young people exposed to religiosity by their parents or in the environment are more passionate about performing religious rites and events. Young people with this background are usually found on social media warmly defending their religious views. The results show that in the majority opinion, religious programs bring some economic benefits to the media industry, but not to a large extent. Moore (1994) described religion as a best-seller. He called it a fashion in American society to sell all things in the name of religion. According to him, labeling religion makes your business more accessible and more profitable.

According to the first hypothesis of this study, the researcher thought that since Geo TV is the mostwatched channel in Pakistan and its rating is higher than other channels, there is a strong possibility that Geo TV also has advertisements. Will meet more. Therefore, the number of advertisements in Geo TV's 
Ramadan transmission will be higher than ARY Digital. But the results did not prove that. There was no significant difference in the duration of advertisements and promos on both channels. That is, the first hypothesis could not prove itself in the light of the survey results. No significant difference was recorded in the duration of advertisements for Geo TV and ARY Digital. Geo TV and ARY Channel are the toprated TV channels in Pakistan, and their policies conflict with each other. Even these two channels do not refrain from running news against each other and the owners of opposing media organizations. Comparing the two channels, Sultan, Iqbal, Khalid \& Ali (2016) proved in the case study that the two channels ran completely different news from each other during the coverage of a case and repeatedly violated the rules PEMRA. This government body regulates the media in Pakistan. Blow up. Therefore, it is not appropriate to expect these two channels to adhere to government laws and media ethics.

\section{Reference}

Abu-Lughod, L. (2006). Local contexts of Islamism in popular media (Vol. 6). Amsterdam University Press.

Bicer, R. (2013). The Interactive Relation between Religious TV Programs and People in Turkey. International Journal of Online Pedagogy and Course Design (IJOPCD), 3(3), 76-84. Casey, C. A. (2006). Virtual ritual, real faith: The revirtualization of religious ritual in cyberspace. Online-Heidelberg Journal of Religions on the Internet, 2.

Christophorou, C., \& Spyridou, L. P. (2017). Media pluralism monitor 2016: monitoring risks for media pluralism in EU and beyond: country report: Cyprus.

Corn-Revere, R., \& Carveth, R. (2003). Economics and media regulation (pp. 59-78). Routledge.

Davie, G. (2007). Vicarious religion: A methodological challenge. Everyday religion: Observing modern religious lives, 21-36.

Ernest-Samuel, G. C. (2017). The role and significance of Multichoice and its Africa Magic channels in the development of Nollywood (Doctoral dissertation).

Hackett, C., \& McClendon, D. (2017). Christians remain world's largest religious group, but they are declining in Europe. Pew Research Center.

Haneef Khan, Z., Watson, P. J., \& Habib, F. (2005). Muslim attitudes toward religion, religious orientation and empathy among Pakistanis. Mental Health, Religion \& Culture, 8(1), 49-61.

Hendriyani, Hollander, E., d'Haenens, L., \& Beentjes, J. W. (2016). Changes in cultural representations on Indonesian children's television from the 1980s to the 2000s. Asian Journal of Communication, 26(4), 371-386.

Juergensmeyer, M. (2006). Religion as a Cause of Terrorism. The roots of terrorism, 1, 133-144.

KARLIDAĞ, S., \& Bulut, S. (2014). The transnational spread of Turkish television soap operas. Ístanbul Üniversitesi İletişim Fakültesi Dergisi| Istanbul University Faculty of Communication Journal, (47), 75-96.

Kiriya, I. (2011). Forms of commodification of public-oriented content in Russia1. Media and Mass communication Laboratory, State university, Higher School of economics, Moscow, Russia.

Lövheim, M. (2013). Introduction: Gender-a blind spot in media, religion and culture?. In Media, Religion and Gender (pp. 11-24). Routledge.

Marx, K. (2007). Capital: A critique of political economy (pp. 63-77). Duke University Press.

Moberg, M., \& Granholm, K. (2017). The concept of the post-secular and the contemporary nexus of religion, media, popular culture, and consumer culture. In Post-secular society (pp. 95127). Routledge.

Morgan, D. L. (2007). Paradigms lost and pragmatism regained: Methodological implications of combining qualitative and quantitative methods. Journal of mixed methods research, 1(1), 48-76.

Mosco, V. (1996). The political economy of communication: Rethinking and renewal (Vol. 13). Sage.

Muzakki, A. (2010). "TEEN ISLAM" The Rise of Teenagers-Segmented Islamic Transmission through Popular Media in Indonesia. Journal of Indonesian Islam, 4(1), 22-42.

Rakhmani, I. (2014). The commercialization of da'wah: Understanding Indonesian Sinetron and 
their portrayal of Islam. International Communication Gazette, 76(4-5), 340-359.

Richerson, P. J., \& Newson, L. (2008). Is religion adaptive? Yes, no, neutral, but mostly, we don't know. The Evolution of Religion: Studies, Theories, and Critiques. Collins Foundation Press, Santa Margarita CA.

Saroglou, V. (2012). Is religion not prosocial at all? Comment on Galen (2012).

Sudcharoen, M. (2013). Commodifying Karma: Abortion Discourses and Kaekam Practices in Thai Society. 